Marquette University

e-Publications@Marquette

7-1-2013

\title{
Preparation of a Semiquinonate-Bridged Diiron(II) Complex and Elucidation of its Geometric and Electronic Structures
}

Amanda E. Baum

Marquette University, amanda.baum@marquette.edu

Sergey V.Lindeman

Marquette University, sergey.lindeman@marquette.edu

Adam T. Fiedler

Marquette University, adam.fiedler@marquette.edu

Accepted version. Chemical Communications, Vol. 49, No. 58 (July 2013): 6531-6533. DOI. (C) 2013 Royal Society of Chemistry. Used with permission. 


\title{
Preparation of a Semiquinonate- Bridged Diiron(II) Complex and Elucidation of its Geometric and Electronic Structures
}

\author{
Amanda E. Baum \\ Department of Chemistry, Marquette University \\ Milwaukee, WI \\ Sergey V. Lindeman \\ Department of Chemistry, Marquette University \\ Milwaukee, WI \\ Adam T. Fiedler \\ Department of Chemistry, Marquette University \\ Milwaukee, WI
}

\section{Abstract}

The synthesis and crystal structure of a diiron(II) complex containing a bridging semiquinonate radical are presented. The unique electronic structure of this $S=7 / 2$ complex is examined with spectroscopic (absorption, EPR, resonance Raman) and computational methods.

p-Hydroquinone (1,4-dihydroxybenzene; HQ) and its substituted derivatives are important biological cofactors due to the ability to 
participate in multiple proton- and electron-transfers. ${ }^{1} \mathrm{HQs}$ undergo reversible one- and two-electron oxidations to yield semiquinone radicals (SQs) and quinones (Qs), respectively. These redox events typically involve loss of proton(s), such that the net reaction is $\mathrm{H}$-atom transfer. ${ }^{2}$ In biochemical processes, HQ cofactors are often associated with one or more redox-active metal ions. For instance, photosystem II incorporates two quinones $\left(\mathrm{Q}_{A}\right.$ and $\left.\mathrm{Q}_{B}\right)$ that shuttle electrons away from the primary electron donor, $\mathrm{P}_{680}{ }^{3}$ In close proximity to both quinones is a nonheme mononuclear Fe center, and recent spectroscopic studies have detected significant magnetic interactions between the high-spin Fe(II)center and semiquinone forms of $\mathrm{Q}_{A}$ and $\mathrm{Q}_{\mathrm{B}}{ }^{4}$ In addition, substituted HQs are generated as part of the microbial breakdown of halogenated and nitro aromatic compounds. In these cases, the HQs are oxidatively degraded by ring-cleaving dioxygenases (HQ dioxygenases, HQDOs) with nonhememonoiron active sites. ${ }^{5}$ Even in these enzymes the electroactive nature of HQs is critical, since the key intermediate in the putative catalytic cycle is a superoxo-Fe(II)-semiquinone complex. ${ }^{6}$

In the course of our efforts to develop synthetic models of HQDOs, we recently prepared the diiron(II) complex $\left[\mathrm{Fe}_{2}\left({ }^{\mathrm{Ph} 2} \mathrm{Tp}\right)_{2}(\mu-\right.$ DMHQ)] (1; Scheme 1), where DMHQ is the dianion of 2,5dimethoxyhydroquinone and ${ }^{\mathrm{Ph}} \mathrm{Tp}$ is hydrotris(3,5-diphenylpyrazol-1$\mathrm{yl}$ )borate $(1-) .{ }^{7} \mathrm{X}$-ray diffraction (XRD) analysis revealed that $\mathbf{1}$ is a centrosymmetric complex with two high-spin, five-coordinate $\mathrm{Fe}$ (II) centers linked by a closed-shell $p$-hydroquinonate ligand (the $\mathrm{Fe} \cdots \mathrm{Fe}$ separation is $8.15 \AA$ ). Here, the magnetic and electrochemical properties of $\mathbf{1}$ are examined in detail. We report that one-electron oxidation of $\mathbf{1}$ yields a unique diiron(II) complex, [2] ${ }^{+}$, containing a bridging $p$-semiquinonate ligand ( $\mathrm{DMSQ}^{\bullet-}$ ). The geometric and electronic structures of $[\mathbf{2}]^{+}$are verified on the basis of crystallographic, spectroscopic, and computational methods. To the best of our knowledge, [2] ${ }^{+}$is the first crystallographicallycharacterized complex to feature Fe(II) center(s) bound to a SQ radical. ${ }^{8,9}$ The results therefore have the potential to advance our fundamental understanding of metal/SQ interactions in biological systems. Moreover, dinuclear complexes with "noninnocent" bridging ligands have attracted considerable attention lately due to their novel electronic and magnetic behavior; ${ }^{10}$ this manuscript contributes a new member to this fascinating class of compounds.

Chemical Communications, Vol. 49, No. 58 (July 2013): pg. 6531-6533. DOI. This article is @ Royal Society of Chemistry and permission has been granted for this version to appear in e-Publications@Marquette. Royal Society of Chemistry does not grant permission for this article to be further copied/distributed or hosted elsewhere without the express permission from Royal Society of Chemistry. 


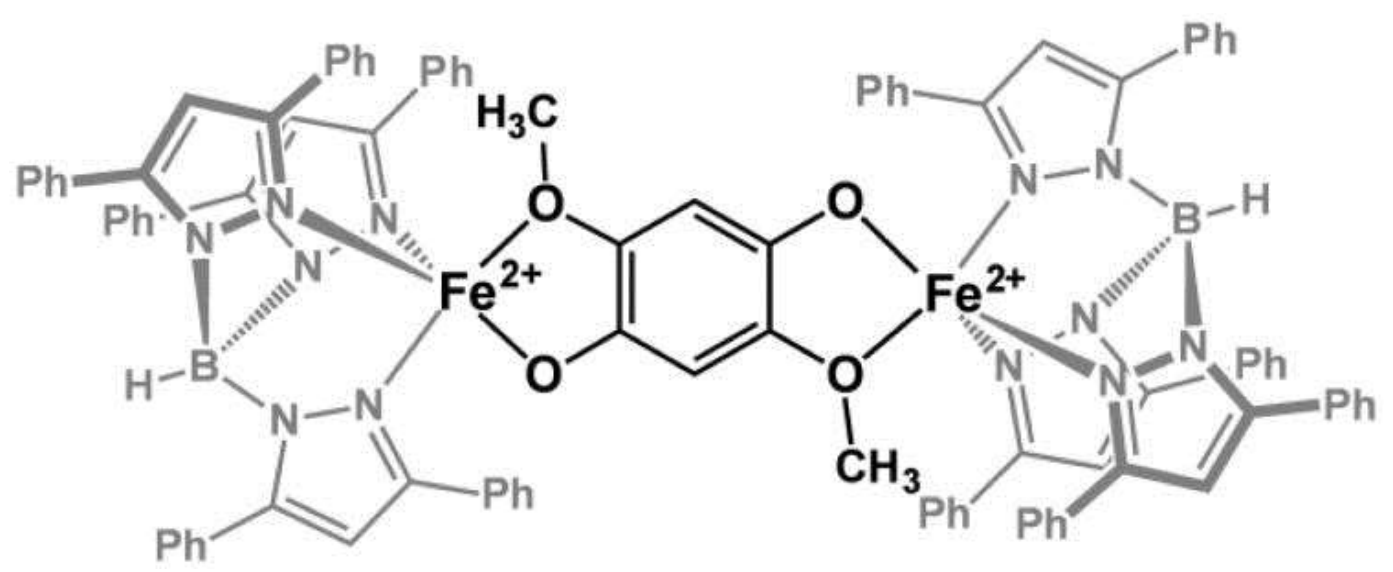

Scheme 1 Structure of complex 1.

Complex $\mathbf{1}$ is easily generated by mixing equimolar amounts of $\mathrm{FeCl}_{2}$ and $\mathrm{K}\left({ }^{\mathrm{Ph} 2} \mathrm{Tp}\right)$ with 0.5 equiv. of $\mathrm{Na}_{2}$ (DMHQ) in $\mathrm{MeCN}$, followed by recrystallization from $\mathrm{CH}_{2} \mathrm{Cl}_{2} / \mathrm{Et}_{2} \mathrm{O} .{ }^{7}$ The ${ }^{1} \mathrm{H}$ NMR spectrum of $\mathbf{1}$ in $\mathrm{CD}_{2} \mathrm{Cl}_{2}$, shown in Fig. S1 (see ESI $\dagger$ ), reveals an abundance of paramagnetically-shifted peaks between $\delta=+60$ and -20 ppm. Using the Evans method, an effective magnetic moment ( $\mu_{\mathrm{eff}}$ ) of $6.3 \mu_{\mathrm{B}}$ was measured at room temperature for $\mathbf{1}$, which is reasonably close to the spin-only value of $6.93 \mu_{\mathrm{B}}$ expected for a molecule with two uncoupled high-spin ( $S=2$ ) Fe(II) centers. Consistent with this result, broken symmetry (BS) calculations ${ }^{11}$ using density functional theory (DFT) computed a J-value (exchange coupling parameter) of $-2 \mathrm{~cm}^{-1}$ for $\mathbf{1}$, indicative of very weak antiferromagnetic interactions. ${ }^{12}$

The redox activity of $\mathbf{1}$ was examined in $\mathrm{CH}_{2} \mathrm{Cl}_{2}$ with $0.1 \mathrm{M}$ $\left[\mathrm{NBu}_{4}\right] \mathrm{PF}_{6}$ as the supporting electrolyte. The cyclic voltammogram (CV) exhibits a reversible couple at $E_{1 / 2}=-570 \mathrm{mV}$ versus $\mathrm{Fc}^{+/ 0}(\Delta E=130$ $\mathrm{mV})$, along with several irreversible events at more positive potentials (Fig. S2, ESI + ). It is instructive to compare this CV to the one reported previously for [Fe( $\left.\left.{ }^{\mathrm{Ph} 2} \mathrm{Tp}\right)(2-\mathrm{MHQ})\right](\mathbf{3}$; where 2-MHQ is the anion of 2methoxyhydroquinone). Even though $\mathbf{1}$ and $\mathbf{3}$ feature nearly identical Fe coordination environments, the latter complex is oxidized at a much higher potential $(-50 \mathrm{mV}) .{ }^{7}$ We therefore surmised that the $-570 \mathrm{mV}$ redox couple of $\mathbf{1}$ corresponds to a ligand-based event. To explore this possibility, complex 1 was treated with 1.0 equivalent of $\mathrm{AgPF}_{6}$ in $\mathrm{CH}_{2} \mathrm{Cl}_{2}$. The resulting orange species $\left([2]^{+}\right)$displays two intense absorption features with $\lambda_{\max }=365$ and $440 \mathrm{~nm}(\varepsilon=13.2$ and 8.0 $\mathrm{mM}^{-1} \mathrm{~cm}^{-1}$, respectively), along with shoulders at $\sim 480$ and $540 \mathrm{~nm}$ 
(Fig. 1). Needle-like crystals of [2] $\mathrm{PF}_{6}$ were obtained by layering a concentrated $\mathrm{CH}_{2} \mathrm{Cl}_{2}$ solution with pentane.

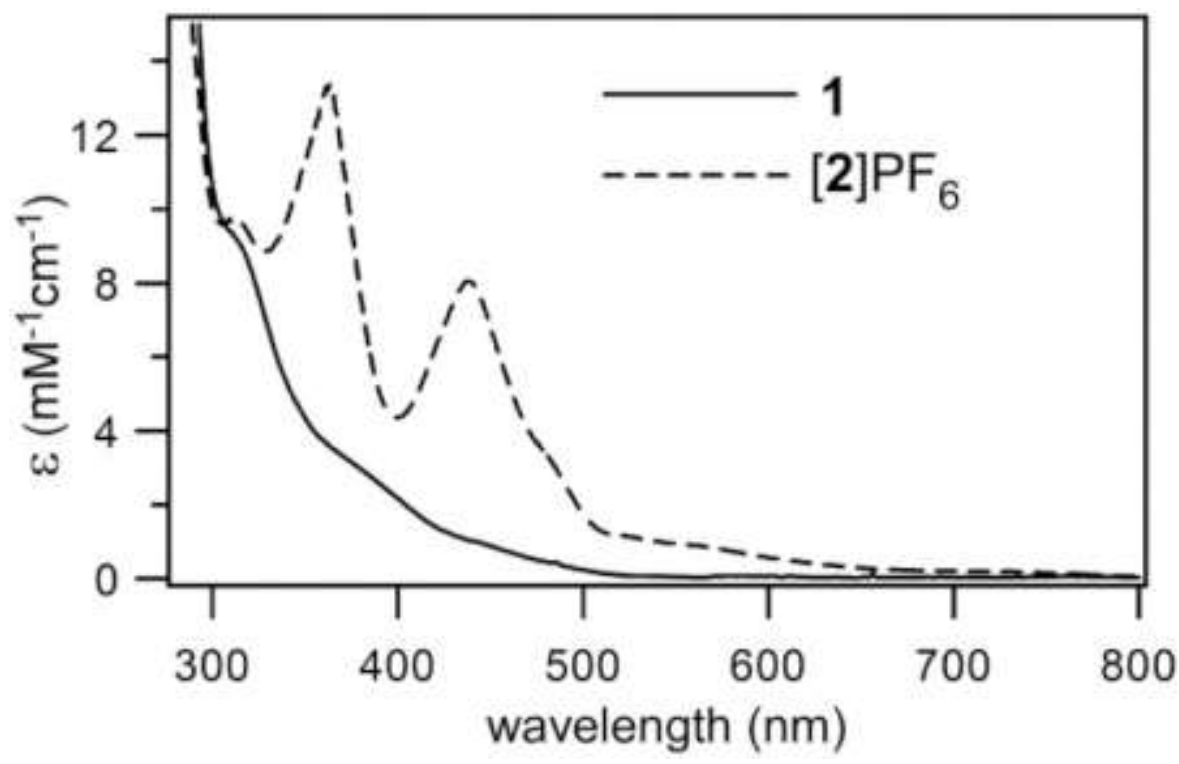

Fig. 1UV-visible spectra of $\mathbf{1}$ and [2] $\mathrm{PF}_{6}$ in $\mathrm{CH}_{2} \mathrm{Cl}_{2}$ at room temperature.

The X-ray structure of $[\mathbf{2}]^{+}$reveals a centrosymmetric diiron unit with the same atomic composition as 1 (Fig. S3, ESI + ). Metric parameters for both complexes are provided in Table 1 . The average $\mathrm{Fe}-\mathrm{N}_{\mathrm{Tp}}$ bond length of $[\mathbf{2}]^{+}(2.094 \AA)$ is only slightly shorter than the value observed for $\mathbf{1}(2.143 \AA)$, suggesting that both Fe centers belong to the ferrous state. The Fe coordination environments are distorted between trigonal-bipyramidal and square pyramidal $\left(\mathrm{T}^{13}=\right.$ 0.34 ). The most dramatic structural changes upon conversion of $\mathbf{1} \rightarrow[\mathbf{2}]^{+}$involve the bridging ligand. In the crystal structure of $\mathbf{1}$, the $\mathrm{C}-\mathrm{C}$ bond lengths of the $\mathrm{DMHQ}^{2-}$ ligand are essentially identical (1.391 $\pm 0.004 \AA$ ) and the 01-C1 distance is $1.329(5) \AA$ - typical values for $p$-hydroquinonate anions. ${ }^{7}$ By contrast, the corresponding ring in $[2]^{+}$displays a pronounced quinoid distortion involving elongation of the $\mathrm{C} 1-\mathrm{C} 2$ and $\mathrm{C} 1-\mathrm{C} 3$ bonds and shortening of the $\mathrm{C} 2-\mathrm{C} 3$ bond. In addition, the $\mathrm{O} 1-\mathrm{C} 1$ distance of $[\mathbf{2}]^{+}$contracts to $1.287(2) \AA$ (Table 1 ). Such metric parameters require a semiquinone assignment for the bridging ligand in $[\mathbf{2}]^{+}$, based on well-established guidelines for the evaluation of dioxolene oxidation states. ${ }^{14}$ Thus, the X-ray diffraction data support our hypothesis that oxidation of $\mathbf{1}$ is a ligand based 
process, such that $[\mathbf{2}]^{+}$is best formulated as $\left[\left(\mathrm{Fe}^{2+}\right)_{2}\left({ }^{\mathrm{Ph} 2} \mathrm{Tp}\right)_{2}(\mu-\right.$ DMSQ) $]^{+}$.

Table 1 Experimental and computed bond distances $(\AA \AA)$ for 1 and $[2]^{\text {ta }}$

\begin{tabular}{llll}
\hline & {$[2] \mathrm{PF}_{6}(\mathrm{XRD})$} & {$[2] \mathrm{PF}_{6}(\mathrm{DFT})$} \\
\hline $\mathrm{Fe} 1-\mathrm{N} 1$ & $1(\mathrm{XRD})$ & $2.125(2)$ & 2.072 \\
$\mathrm{Fe} 1-\mathrm{N} 3$ & $2.107(4)$ & $2.076(2)$ & 2.051 \\
$\mathrm{Fe} 1-\mathrm{N} 5$ & $2.108(3)$ & $2.082(2)$ & 2.067 \\
$\mathrm{Fe} 1-\mathrm{O} 1$ & $2.213(4)$ & $1.940(1)$ & 1.909 \\
$\mathrm{Fe} 1-\mathrm{O} 2$ & $1.904(3)$ & $1.287(2)$ & 1.303 \\
$\mathrm{O} 1-\mathrm{C} 1$ & $2.328(3)$ & $1.358(2)$ & 1.360 \\
$\mathrm{O} 2-\mathrm{C} 2$ & $1.329(5)$ & $1.446(2)$ & 1.449 \\
$\mathrm{C} 1-\mathrm{C} 2$ & $1.388(6)$ & $1.415(2)$ & 1.381 \\
$\mathrm{C} 1-\mathrm{C} 3$ & $1.395(7)$ & $1.366(2)$ & 0.74 \\
$\mathrm{C} 2-\mathrm{C} 3$ & $1.388(6)$ & 0.34 & \\
$\tau-\mathrm{Value} 13$ & $1.389(7)$ & 0.59 &
\end{tabular}

${ }^{a}$ Both 1 and [2] $\mathrm{PF}_{6}$ are centrosymmetric compounds.

The electronic structure of [2]PF 6 was examined with spectroscopic and computational techniques. The X-band EPR spectrum exhibits a peak at $g_{\text {eff }}=13.9$ and a derivative-shaped feature at $g_{\text {eff }}=5.4$ (Fig. 2). Since half-integer spin systems cannot give rise to features with $g_{\text {eff }}>4 S$ (assuming real $g$-values near 2.0 ), ${ }^{15}$ the EPR results suggest that [2]+ possesses a spin of $7 / 2$. Indeed, as shown in Fig. 2, the data is nicely simulated assuming $S=7 / 2$ and the following spin-Hamiltonian parameters: $D=+7(2) \mathrm{cm}^{-1}, E / D=$ $0.11(2)$, and $g_{\text {real }}=2.3,2.2,2.1 .{ }^{16}$ These values were obtained by fitting EPR spectra measured at temperatures ranging from 5 to $20 \mathrm{~K}$. The $g=13.9$ peaks therefore arises from the lowest-energy $M_{S}=$ $\pm 1 / 2$ doublet, while the derivative signal at 5.4 is due to the $M_{S}=$ 
$\pm 3 / 2$ doublet; ${ }^{15}$ as expected, the former diminishes at higher temperatures while the latter gains in relative intensity (Fig. S4, ESI + ).

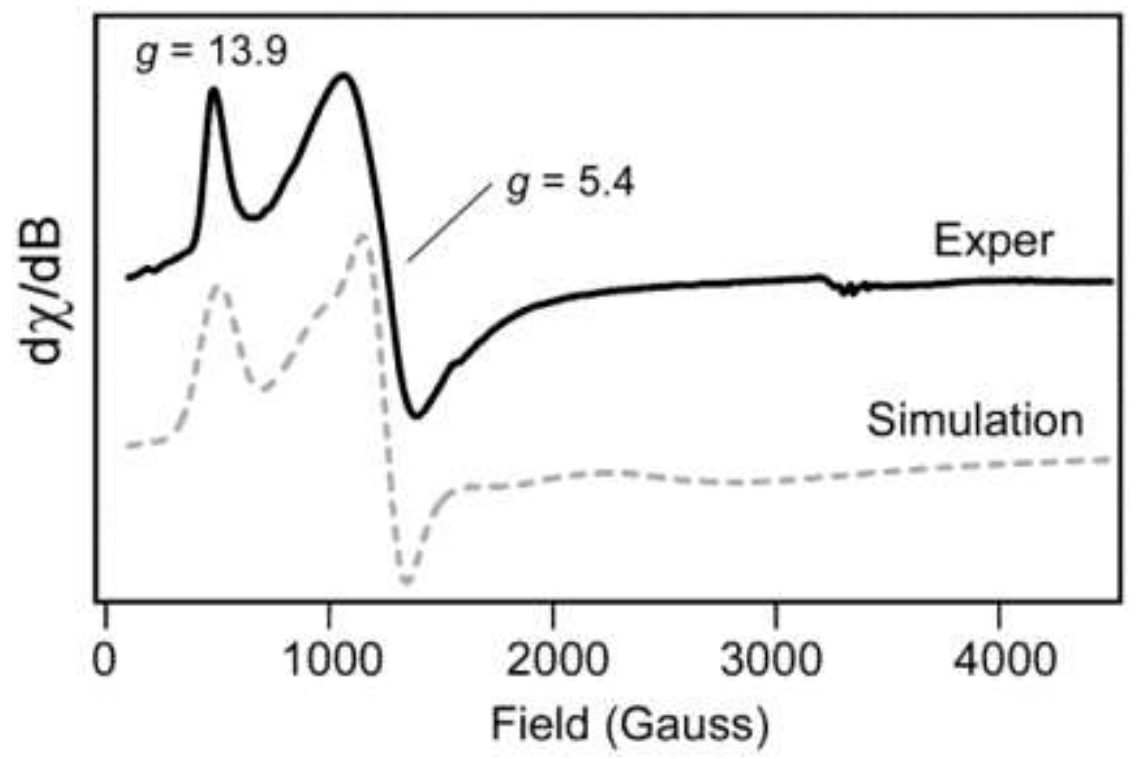

Fig. 2 X-band EPR spectrum of [2] $\mathrm{PF}_{6}$ in a frozen $\mathrm{CH}_{2} \mathrm{Cl}_{2}$ solution (4 mM) collected at $10 \mathrm{~K}$. Parameters used to generate the simulated spectrum are given in the text.

The electronic origin of this unique EPR signal was elucidated with the aid of DFT. Using the crystallographic coordinates, a calculation with $S=7 / 2$ converged to a wavefunction consisting of two high-spin $\mathrm{Fe}$ (II) centers antiferromagnetically coupled to the bridging DMSQ radical (Fig. 3, left). Geometry optimizations indicate that this electronic configuration is the most stable one on the $S=7 / 2$ surface (bond distances for the optimized model are shown in Table 1). A Jvalue of $-83 \mathrm{~cm}^{-1}$ per Fe/DMSQ interaction was computed using the BS formalism. ${ }^{17}$ Thus, unlike the closed-shell DMHQ ligand, the bridging radical in $[\mathbf{2}]^{+}$is capable of mediating significant exchange interactions between the Fe-based spins, which are separated by 8.22 $\AA$ in the crystal structure. A similar spin topology was observed by Dei and Gatteschi for a diferric complex containing a bridging SQ ligand. ${ }^{18}$ In this case, the overall spin is $9 / 2$ and the $J$-value is considerably larger at $-370 \mathrm{~cm}^{-1}$. 


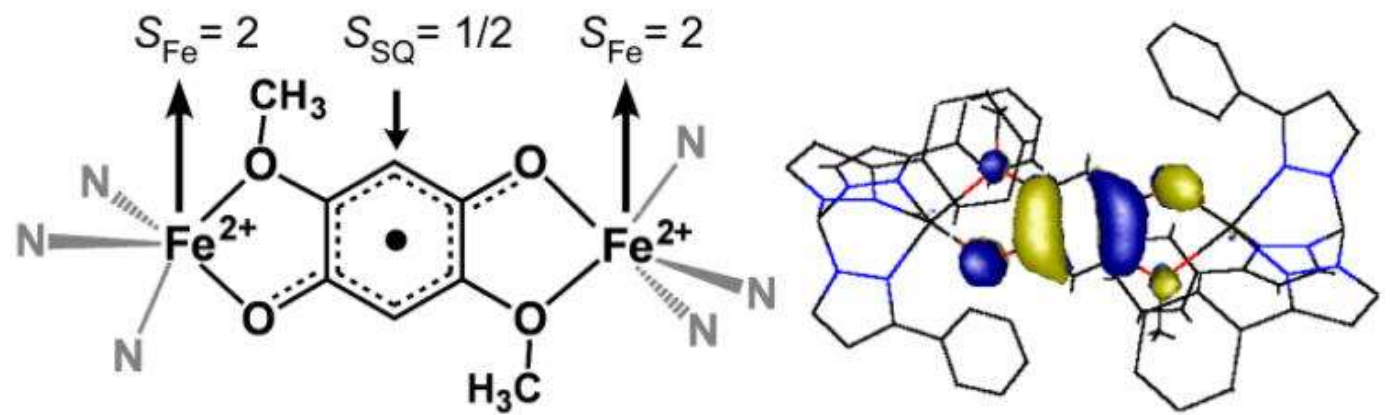

Fig. 3 (Left) Spin coupling topology for [2] that gives rise to overall spin of $7 / 2$. (Right) DFT-generated isosurface plot of the [2] $]^{+}$SOMO.

The radical character of the $[\mathbf{2}]^{+}$bridging ligand is illustrated by the singly-occupied molecular orbital (SOMO) shown in Fig. 4, which is almost exclusively localized on DMSQ. This MO contributes to the intense electronic transitions that appear in the visible region, according to time-dependent DFT (TD-DFT) calculations that reproduce the experimental $[\mathbf{2}]^{+}$spectrum reasonably well (Fig. S5, ESI ${ }^{+}$). TDDFT attributes the absorption manifold centered at $440 \mathrm{~nm}$ to multiple $\mathrm{Fe}$ (II) $\rightarrow$ DMSQ metal-to-ligand charge transfer (CT) transitions, while the higher-energy feature at $365 \mathrm{~nm}$ arises from a single $\mathrm{DMSQ} \rightarrow \mathrm{Fe}$ (II) ligand-to-metal CT transition. It appears that the existence of a ligand radical in [2] ${ }^{+}$is favored by the presence of lowsymmetry, five-coordinate Fe(II) geometries, which stabilize the Fe $3 \mathrm{~d}$-orbitals and remove their degeneracy. ${ }^{19}$

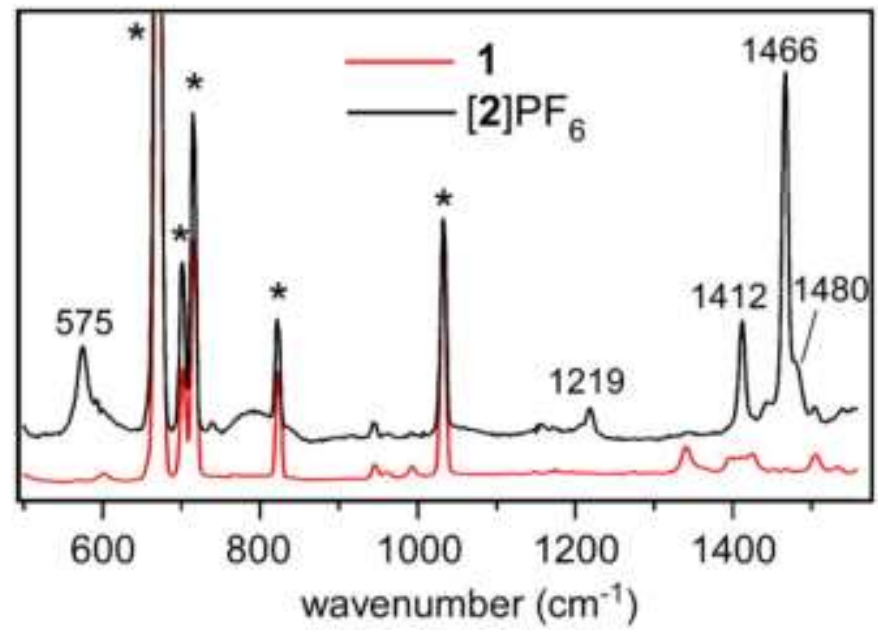

Fig. $4 \mathrm{rR}$ spectra of frozen $\mathrm{CD}_{2} \mathrm{Cl}_{2}$ solutions of $\mathbf{1}$ (red, bottom) and [2] $\mathrm{PF}_{6}$ (black, top) obtained with $457.9 \mathrm{~nm}$ excitation. $*$ = solvent peaks 
The nature of the bridging ligand was further probed via resonance Raman (rR) spectroscopy. As shown in Fig. 4, the [2] ${ }^{+}$ spectrum exhibits several intense peaks that are not evident in the precursor spectrum. The dominant feature at $1466 \mathrm{~cm}^{-1}$ is strongly enchanced by excitation into $440 \mathrm{~nm}$ absorption feature (Fig. S6, $\mathrm{ESI}+$ ), indicating that it corresponds to a DMSQ-based mode. The rR spectra of metal-bound $o$-dioxolenes typically display prominent peaks arising from $\mathrm{C}-\mathrm{O}$ stretching modes. The frequencies of these modes are diagnostic of ligand oxidation state, appearing at $1250-1275 \mathrm{~cm}^{-1}$ for catecholates, $1400-1500 \mathrm{~cm}^{-1}$ for $o$-semiquinones, and $1620-1640$ $\mathrm{cm}^{-1}$ for $\mathrm{o}$-benzoquinones. ${ }^{14 \mathrm{~b}}$ It is therefore reasonable to assign the dominant feature at $1466 \mathrm{~cm}^{-1}$ to the symmetric $\mathrm{v}(\mathrm{O} 1-\mathrm{C} 1)$ mode of $[2]^{+}$. Literature precedents indicate that the $575 \mathrm{~cm}^{-1}$ peak corresponds to the breathing mode of the five-membered chelates formed by each Fe center and the DMSQ ligand, while the resonanceenhanced peaks at 1412 and $1480 \mathrm{~cm}^{-1}$ likely involve modes that strongly mix $\mathrm{v}(\mathrm{O} 1-\mathrm{C} 1)$ and intraligand $\mathrm{C}-\mathrm{C}$ bond motions. ${ }^{20}$ The $\mathrm{rR}$ data thus provides additional evidence for the presence of a DMSQ ligand in $[\mathbf{2}]^{+}$.

The results presented here open up intriguing possibilities for future research. The fact that the ligand-to-metal and metal-to-ligand $\mathrm{CT}$ bands of $[\mathbf{2}]^{+}$appear in close proximity (vide supra) indicates that the Fe- and DMSQ-based orbitals are nearly isoenergetic, making it difficult to predict whether further oxidations would be ligand- or ironcentered. Studies are therefore underway to examine the electronic structure of the species generated via one-electron oxidation of [2] $]^{+}$. In addition, we are developing mononuclear $\mathrm{Fe}(\mathrm{II}) / \mathrm{semiquinone}$ complexes that mimic the putative catalytic intermediate of HQDOs.

\section{Acknowledgments}

The authors thank Dr. Brian Bennett for allowing us to measure EPR data at the National Biomedical EPR Center (supported by NIH P41 Grant EB001980), and Thomas Brunold (Univ. Wisconsin) for access to his rR instrument. This research is supported by the National Science Foundation (CHE-1056845).

\section{Footnotes}

Chemical Communications, Vol. 49, No. 58 (July 2013): pg. 6531-6533. DOI. This article is (C) Royal Society of Chemistry and permission has been granted for this version to appear in e-Publications@Marquette. Royal Society of Chemistry does not grant permission for this article to be further copied/distributed or hosted elsewhere without the express permission from Royal Society of Chemistry. 
NOT THE PUBLISHED VERSION; this is the author's final, peer-reviewed manuscript. The published version may be accessed by following the link in the citation at the bottom of the page.

${ }^{\dagger}$ Electronic Supplementary Information (ESI) available: Experimental and computational details, and additional data. CCDC 934969 ([2]PF6).

\section{Notes and References}

1. (a) Weinberg DR, Gagliardi CJ, Hull JF, Murphy CF, Kent CA, Westlake BC, Paul A, Ess DH, McCafferty DG, Meyer TJ. Chem Rev. 2012;112:40164093. (b) Efremov RG, Sazanov LA. BBA-Bioenergetics. 2012;1817:1785-1795.

2. (a) Warren JJ, Tronic TA, Mayer JM. Chem Rev. 2010;110:6961-7001. (b) Huynh MHV, Meyer TJ. Chem Rev. 2007;107:5004-5064.

3. (a) Muh F, Glockner C, Hellmich J, Zouni A. BBA-Bioenergetics. 2012;1817:44-65. (b) Ferreira KN, Iverson TM, Maghlaoui K, Barber J, Iwata S. Science. 2004;303:1831-1838.

4. (a) Sedoud A, Cox N, Sugiura M, Lubitz W, Boussac A, Rutherford AW. Biochemistry. 2011;50:6012-6021. (b) Cox N, Jin L, Jaszewski A, Smith PJ, Krausz E, Rutherford AW, Pace R. Biophys J. 2009;97:20242033.

5. Vaillancourt FH, Bolin JT, Eltis LD. Crit Rev Biochem Mol Biol. 2006;41:241-267.

6. Machonkin TE, Doerner AE. Biochemistry. 2011;50:8899-8913.

7. Baum AE, Park H, Wang DN, Lindeman SV, Fiedler AT. Dalton Trans. 2012;41:12244-12253.

8. Min et al. reported a diiron(II) complex bridged by a chloranilate radical (ref ${ }^{9}$ ). However, this complex did not provide suitable crystals for X-ray crystallography.

9. Min KS, DiPasquale AG, Golen JA, Rheingold AL, Miller JS. J Am Chem Soc. 2007; 129:2360-2368.

10. (a) Kaim W. Inorg Chem. 2011;50:9752-9765. (b) Miller JS, Min KS. Angew Chem Intl Ed. 2009;48:262-272. (c) Min KS, DiPasquale AG, Rheingold AL, White HS, Miller JS. J Am Chem Soc. 2009;131:62296236.

11. Sinnecker S, Neese F, Noodleman L, Lubitz W. J Am Chem Soc. 2004; 126:2613-2622.

12. Yamaguchi K, Takahara Y, Fueno T. In: Applied Quantum Chemistry. Smith VH, editor. Reidel; Dordrecht: 1986. p. 155.

13. Addison AW, Rao TN, Reedijk J, Vanrijn J, Verschoor GC. J Chem Soc, Dalton Trans. 1984:1349-1356.

14. (a) Attia AS, Conklin BJ, Lange CW, Pierpont CG. Inorg Chem. 1996;35:1033-1038. (b) Vlcek A. Comments Inorg Chem. 1994;16:207-228.(c) Chaudhuri P, Verani CN, Bill E, Bothe E, Weyhermuller T, Wieghardt K. J Am Chem Soc. 2001;123:2213-2223.

Chemical Communications, Vol. 49, No. 58 (July 2013): pg. 6531-6533. DOI. This article is @ Royal Society of Chemistry and permission has been granted for this version to appear in e-Publications@Marquette. Royal Society of Chemistry does not grant permission for this article to be further copied/distributed or hosted elsewhere without the express permission from Royal Society of Chemistry. 
15. Hagen WR. In: Adv Inorg Chem. Cammack R, editor. Vol. 38. Academic Press; San Diego, CA: 1992. pp. 165-222.

16. Attempts to reproduce the data assuming a spin of $5 / 2$ required unrealistically large greal values.

17. Experimentally, the variable-temperature EPR data (Fig. S4) provides a lower-limit for the $J$-value. Since a signal from the $S=5 / 2$ excited state is not observed in the $20 \mathrm{~K}$ spectrum, we can assume that its population is less than $\sim 1 \%$ at this temperature. This requires a Jvalue greater than $-40 \mathrm{~cm}^{-1}$.

18. Dei A, Gatteschi D, Pardi L, Russo U. Inorg Chem. 1991;30:2589-2594.

19. Allard MM, Sonk JA, Heeg MJ, McGarvey BR, Schlegel HB, Verani CN. Angew Chem Intl Ed. 2012;51:3178-3182.

20. (a) Holt BTO, Vance MA, Mirica LM, Heppner DE, Stack TDP, Solomon EI. J Am Chem Soc. 2009;131:6421-6438. (b) Hartl F, Stufkens DJ, Vlcek A. Inorg Chem. 1992;31:1687-1695.

\section{Supplementary Material}

\section{Crystal data:}

http://www.ncbi.nlm.nih.gov/pmc/articles/PMC3860832/bin/NIHMS496449supplement-Crystal_data.cif (43K, cif)

\section{ESI:}

http://www.ncbi.nlm.nih.gov/pmc/articles/PMC3860832/bin/NIHMS496449supplement-ESI.pdf (1.0M, pdf)

\section{Experimental Section}

General methods: All reagents and solvents were purchased from commercial sources and used as received unless otherwise noted. Dichloromethane was purified and dried using a Vacuum Atmospheres solvent purification system. The compounds 2,5-

dimethoxyhydroquinone ${ }^{1}$ and $\mathrm{K}\left({ }^{\mathrm{Ph} 2} \mathrm{Tp}\right)^{2}$ were prepared according to literature procedures. The synthesis of complex $\mathbf{1}$ was reported in our previous manuscript. ${ }^{3}$ The synthesis and handling of air-sensitive materials were carried out under an inert atmosphere using a Vacuum Atmospheres Omni-Lab glovebox.

Preparation of [2] $\mathbf{P F}_{\mathbf{6}}:\left[\mathrm{Fe}_{2}\left({ }^{\mathrm{Ph} 2} \mathrm{Tp}\right)_{2}(\mu-\mathrm{DMHQ})\right](\mathbf{1}, 98.0 \mathrm{mg}, 0.0605$ mmol) was treated with one equivalent of $\mathrm{AgPF}_{6}(16.1 \mathrm{mg}, 0.0637$ $\mathrm{mmol})$ in $\mathrm{CH}_{2} \mathrm{Cl}_{2}(10 \mathrm{~mL})$ for one hour. The resulting dark brown solution was filtered through celite and concentrated to approximately

Chemical Communications, Vol. 49, No. 58 (July 2013): pg. 6531-6533. DOI. This article is @ Royal Society of Chemistry and permission has been granted for this version to appear in e-Publications@Marquette. Royal Society of Chemistry does not grant permission for this article to be further copied/distributed or hosted elsewhere without the express permission from Royal Society of Chemistry. 
half of its original volume. Layering of this solution with pentane provided dark brown needles suitable for X-ray crystallography (69 $\mathrm{mg}, 62 \%$ ). The $\mathrm{X}$-ray structure found one uncoordinated $\mathrm{CH}_{2} \mathrm{Cl}_{2}$ molecule per unit cell, and elemental analysis indicates that some solvent ( 0.4 equiv.) remains after drying. Anal. Calcd for $\mathrm{C}_{98} \mathrm{H}_{76} \mathrm{~B}_{2} \mathrm{~F}_{6} \mathrm{Fe}_{2} \mathrm{~N}_{12} \mathrm{O}_{4} \mathrm{P} \cdot 0.4 \mathrm{CH}_{2} \mathrm{Cl}_{2}\left(\mathrm{MW}=1797.99 \mathrm{gmol}^{-1}\right): \mathrm{C}, 65.73 ; \mathrm{H}$, $4.31 ; \mathrm{N}, 9.35$. Found: $\mathrm{C}, 65.77 ; \mathrm{H}, 4.00 ; \mathrm{N}, 9.54$. FTIR $\left(\mathrm{cm}^{-1}\right.$, solid): $3051,2616[\square(\mathrm{B} \square \mathrm{H})], 1516,1495,1477,1464,1431,1414,1207$, $1163,1065,1009,833,759,694,668$.

Physical measurements: Elemental analyses were performed at Midwest Microlab, LLC in Indianapolis, IN. Infrared (IR) spectra of solid samples were measured with a Thermo Scientific Nicolet iS5 FTIR spectrometer equipped with the iD3 attenuated total reflectance accessory. UV-vis spectra were obtained with an Agilent 8453 diode array spectrometer. Magnetic susceptibility measurements were carried out using the Evans NMR method.

Cyclic voltammetric (CV) measurements were conducted in the glovebox with an epsilon EC potentiostat (iBAS) at a scan rate of 100 $\mathrm{mV} / \mathrm{s}$ with $100 \mathrm{mM}$ (NBu4)PF 6 . A three-electrode cell containing a $\mathrm{Ag} / \mathrm{AgCl}$ reference electrode, a platinum auxiliary electrode, and a glassy carbon working electrode was employed. Under these conditions, the ferrocene/ferrocenium $\left(\mathrm{Fc}^{+/ 0}\right)$ couple has an $\mathrm{E}_{1 / 2}$ value of $+0.52 \mathrm{~V}$ in $\mathrm{CH}_{2} \mathrm{Cl}_{2}$.

EPR experiments were performed using a Bruker ELEXSYS E600 equipped with an ER4415DM cavity resonating at $9.63 \mathrm{GHz}$, an Oxford Instruments ITC503 temperature controller and ESR-900 He flow cryostat. The program EasySpin ${ }^{4}$ was used to simulate the experimental spectra.

Resonance Raman ( $r R$ ) spectra were obtained upon excitation with a Coherent I-305 $\mathrm{Ar}^{+}$laser with $\sim 45 \mathrm{~mW}$ of laser power at the sample. The scattered light was collected using a $135^{\circ}$ backscattering arrangement, dispersed by an Acton Research triple monochromator equipped with a 1200 groves $/ \mathrm{mm}$ grating and analyzed with a Princeton Instruments Spec $X$ 100BR deep depletion, back-thinned CCD camera. Solution samples of $\mathbf{1}$ and $[\mathbf{2}] \mathrm{PF}_{6}$ were prepared in 
$\mathrm{CD}_{2} \mathrm{Cl}_{2}$ with concentrations of 4.8 and $3.1 \mathrm{mM}$, respectively. Spectra were accumulated at $77 \mathrm{~K}$ by inserting the samples (contained in an NMR tube) in an EPR dewar filled with liquid $N_{2}$. rR excitation profiles were measured by quantifying the sample peak intensities relative to the $1032 \mathrm{~cm}^{-1}$ peak of frozen $\mathrm{CD}_{2} \mathrm{Cl}_{2}$.

Crystallographic studies: X-ray diffraction (XRD) data were collected with an Oxford Diffraction SuperNova kappa-diffractometer (Agilent Technologies) equipped with dual microfocus $\mathrm{Cu} / \mathrm{Mo} \mathrm{X}$-ray sources, X-ray mirror optics, Atlas CCD detector, and low-temperature Cryojet device. The data were processed with CrysAlis Pro program package (Agilent Technologies, 2011) typically using a numerical Gaussian absorption correction (based on the real shape of the crystal), followed by an empirical multi-scan correction using SCALE3 ABSPACK routine. The structures were solved using SHELXS program and refined with SHELXL program ${ }^{5}$ within Olex2 crystallographic package. ${ }^{6} \mathrm{~B}$-and $\mathrm{C}$-bonded hydrogen atoms were positioned geometrically and refined using appropriate geometric restrictions on the corresponding bond lengths and bond angles within a riding/rotating model (torsion angles of methyl hydrogens were optimized to better fit the residual electron density).

Crystallographic data for [2] $\mathrm{PF}_{6} \cdot \mathrm{CH}_{2} \mathrm{Cl}_{2}$ : $\mathrm{C}_{99} \mathrm{H}_{78} \mathrm{~B}_{2} \mathrm{Cl}_{2} \mathrm{~F}_{6} \mathrm{Fe}_{2} \mathrm{~N}_{12} \mathrm{O}_{4} \mathrm{P}, \mathrm{Mr}=$ $1848.95 \mathrm{~g} \mathrm{~mol}^{-1}$, triclinic, space group $P-1, a=9.7382(3), b=$ 13.2530(4), $c=18.0619(7) \AA, \alpha=103.453(3), \beta=104.559(3), \gamma=$ 97.098(3)o, $V=2152.89(13) \AA^{3}, Z=1, \rho=1.428 \mathrm{~g} \mathrm{~cm}^{-3}$, total data 42432 , independent reflections $8566\left(R_{\text {int }}=0.0395\right), 624$ parameters, $R_{1}=0.0393$ for $\mathrm{I} \geq 2 \sigma(\mathrm{I})$ and $w R_{2}=0.1024$.

DFT calculations: DFT calculations were performed using the ORCA 2.8 software package developed by Dr. F. Neese. ${ }^{7}$ Geometry optimizations employed the Becke-Perdew (BP86) functional, 8 while single-point (SP) and time-dependent DFT (TD-DFT) calculations used Becke's three-parameter hybrid functional for exchange along with the Lee-Yang-Parr correlation functional (B3LYP). ${ }^{9}$ SP and TD-DFT calculations were based on modified crystallographic coordinates in which the phenyl groups at the 5-position of the pyrazole ligands were replaced by hydrogen atoms. Ahlrichs' valence triple- $\zeta$ basis set (TZV), in conjunction with the $\mathrm{TZV} / \mathrm{J}$ auxiliary basis set, ${ }^{10}$ were used for all 
NOT THE PUBLISHED VERSION; this is the author's final, peer-reviewed manuscript. The published version may be accessed by following the link in the citation at the bottom of the page.

calculations TD-DFT calculations ${ }^{11}$ computed absorption energies and intensities within the Tamm-Dancoff approximation. ${ }^{12}$ In each case, at least 60 excited states were calculated. The gOpenMol program ${ }^{13}$ developed by Laaksonen was used to generate isosurface plots of molecular orbitals.

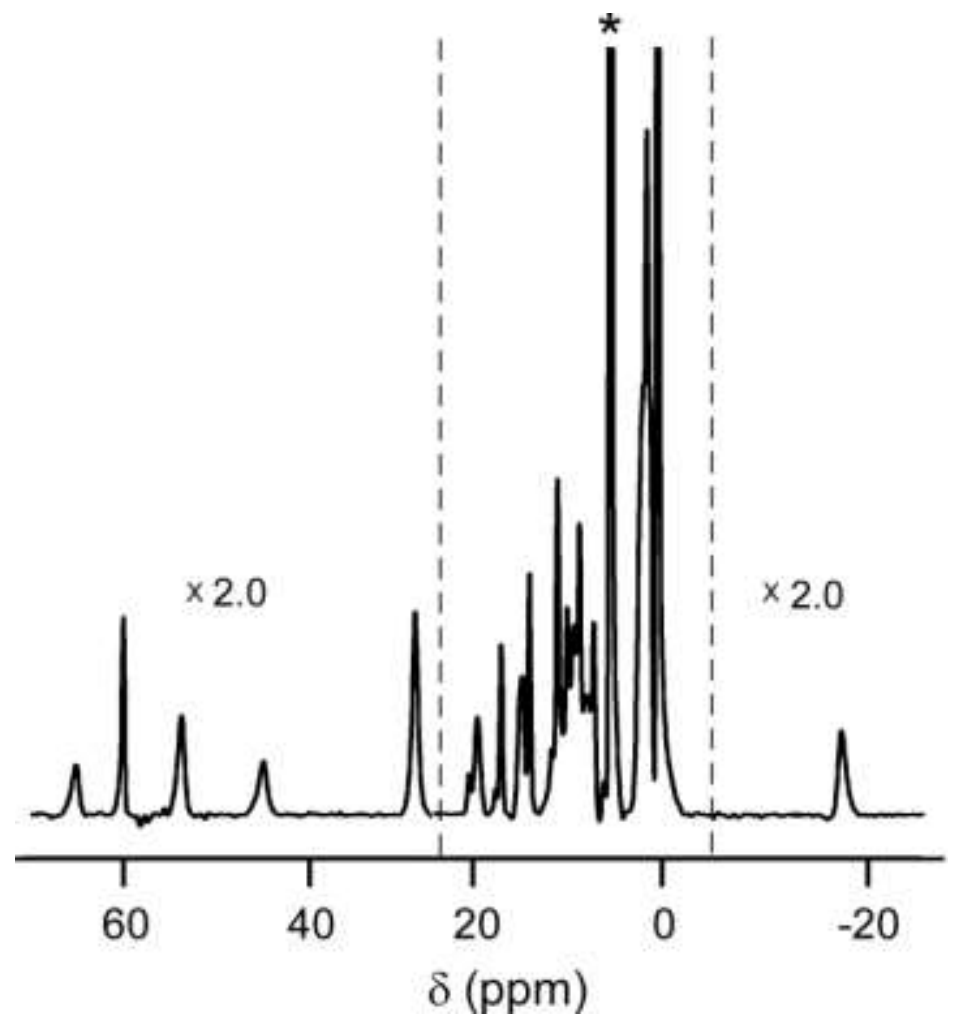

Figure S1. ${ }^{1} \mathrm{H}$ NMR spectra of $\mathbf{1}$ in $\mathrm{CD}_{2} \mathrm{Cl}_{2}$. Peak intensities for the outer portions of the spectra were enlarged $(\times 2)$ for the sake of clarity. The solvent-derived peak is indicated with an asterisk $(*)$.

Chemical Communications, Vol. 49, No. 58 (July 2013): pg. 6531-6533. DOI. This article is @ Royal Society of Chemistry and permission has been granted for this version to appear in e-Publications@Marquette. Royal Society of Chemistry does not grant permission for this article to be further copied/distributed or hosted elsewhere without the express permission from Royal Society of Chemistry. 
NOT THE PUBLISHED VERSION; this is the author's final, peer-reviewed manuscript. The published version may be accessed by following the link in the citation at the bottom of the page.

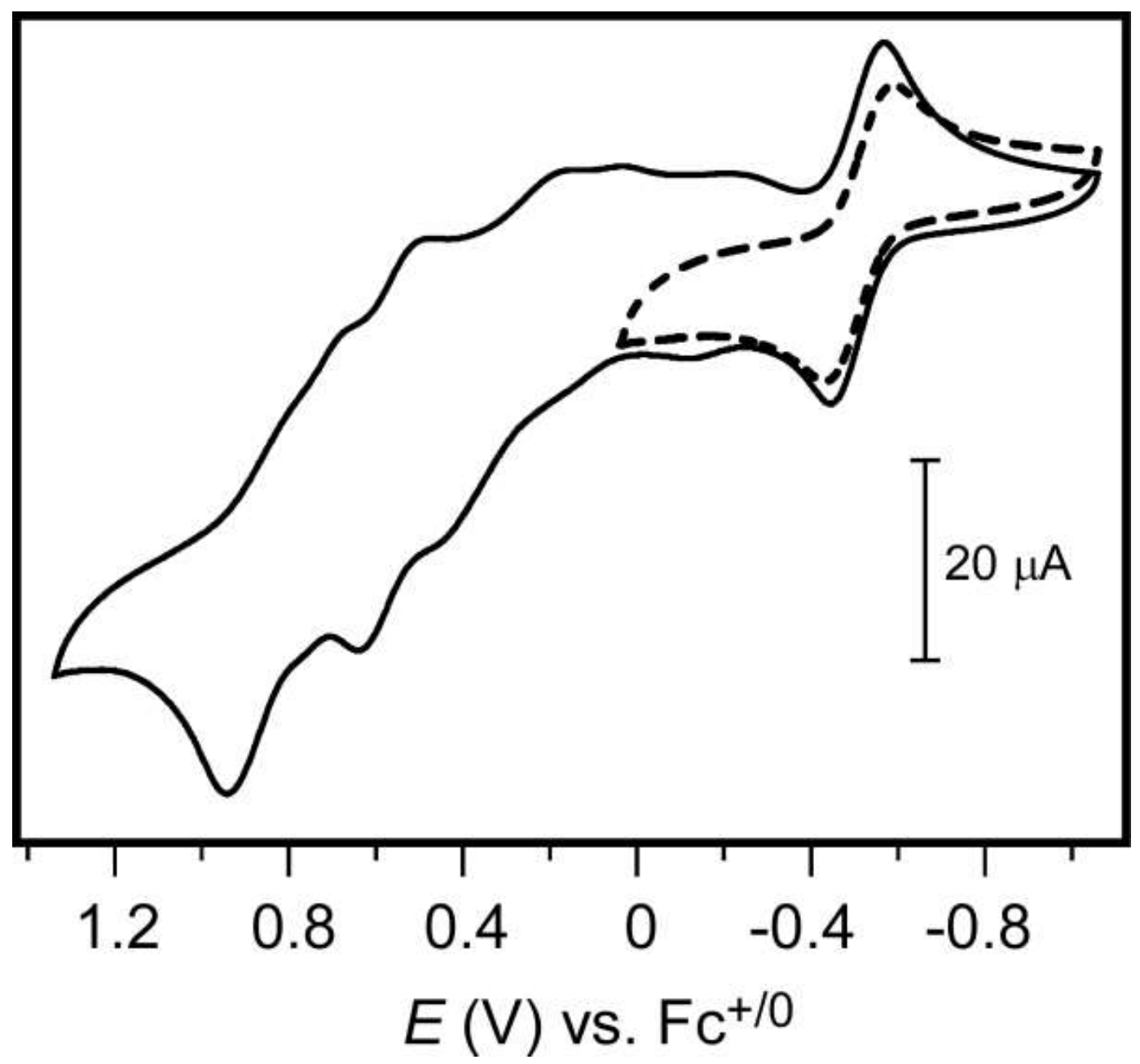

Figure S2. Cyclic voltammograms of complex 1 measured in $\mathrm{CH}_{2} \mathrm{Cl}_{2}$ with $100 \mathrm{mM}$ $\left(\mathrm{NBu}_{4}\right) \mathrm{PF}_{6}$ as the supporting electrolyte and a scan rate of $100 \mathrm{mVs}^{-1}$.

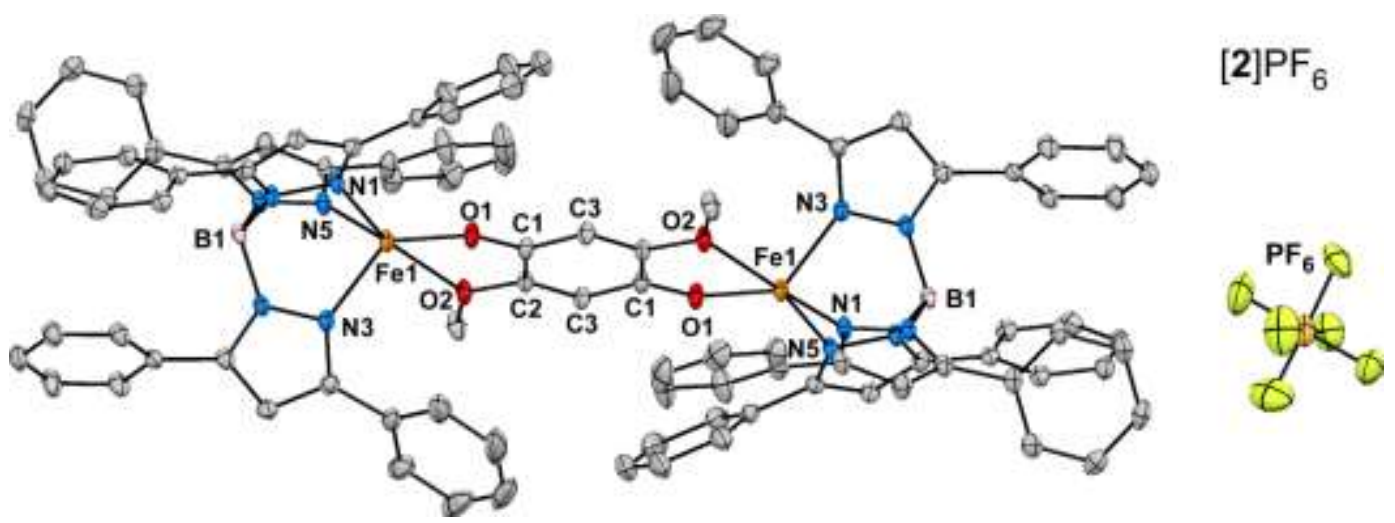

Figure S3. Thermal ellipsoid plot (50\% probability) derived from the X-ray structure of [2] $\mathrm{PF}_{6} \bullet \mathrm{CH}_{2} \mathrm{Cl}_{2}$. Non-coordinating solvent molecules and hydrogen atoms have been omitted for clarity. Key metric parameters are provided in Table 1.

Chemical Communications, Vol. 49, No. 58 (July 2013): pg. 6531-6533. DOI. This article is @ Royal Society of Chemistry and permission has been granted for this version to appear in e-Publications@Marquette. Royal Society of Chemistry does not grant permission for this article to be further copied/distributed or hosted elsewhere without the express permission from Royal Society of Chemistry. 


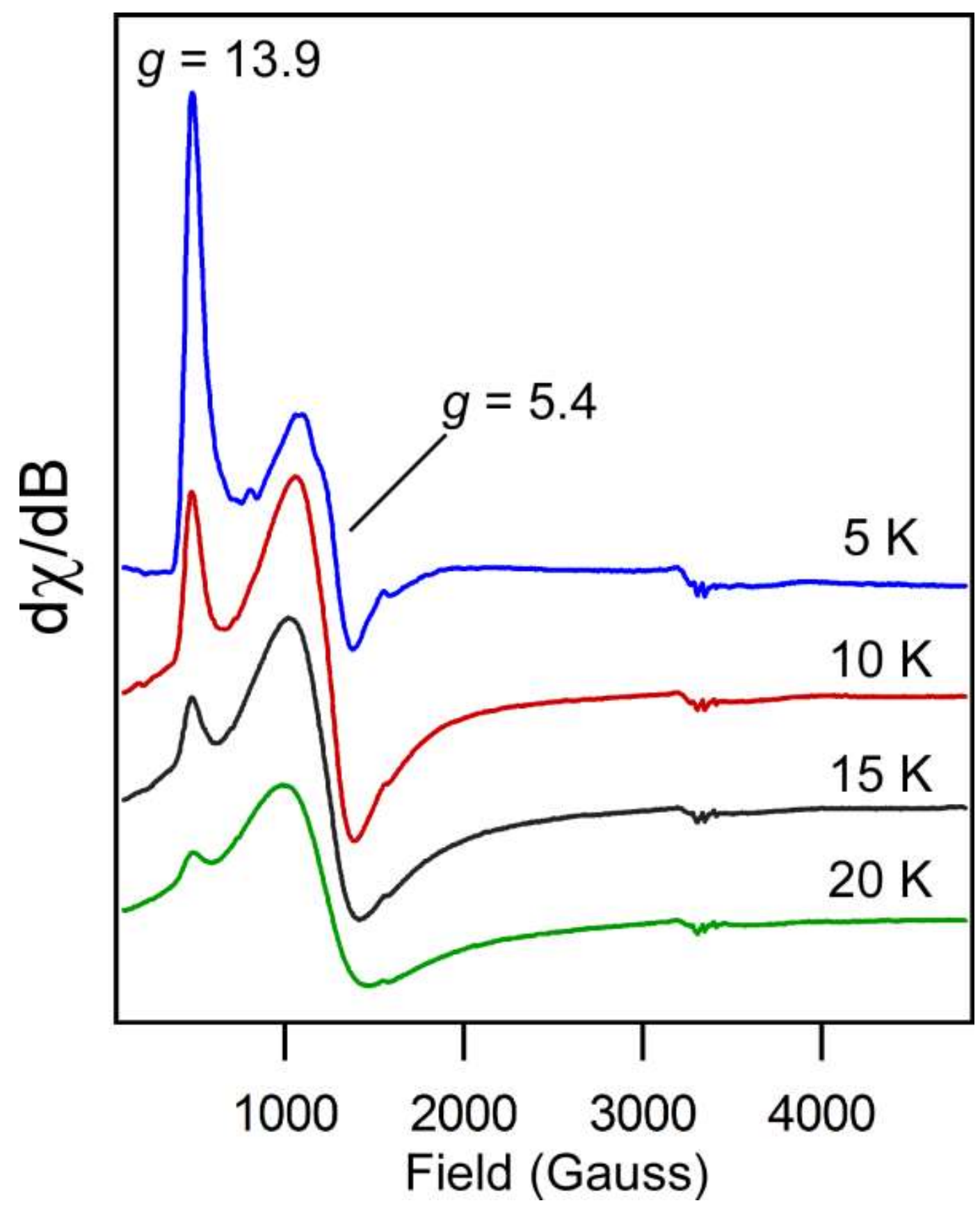

Figure S4. $X$-band EPR spectra of [2]PF 6 at various temperatures $(5,10,15$, and $20 \mathrm{~K}$ ) in frozen $\mathrm{CH}_{2} \mathrm{Cl}_{2}$ solution $(4 \mathrm{mM})$. Experimental parameters: frequency $=9.38$ $\mathrm{GHz}$; microwave power $=2.0 \mathrm{~mW}$; modulation amplitude $=10.0$ Gauss; modulation frequency $=100 \mathrm{kHz}$. and permission has been granted for this version to appear in e-Publications@Marquette. Royal Society of Chemistry does not grant permission for this article to be further copied/distributed or hosted elsewhere without the express permission from Royal Society of Chemistry. 
NOT THE PUBLISHED VERSION; this is the author's final, peer-reviewed manuscript. The published version may be accessed by following the link in the citation at the bottom of the page.
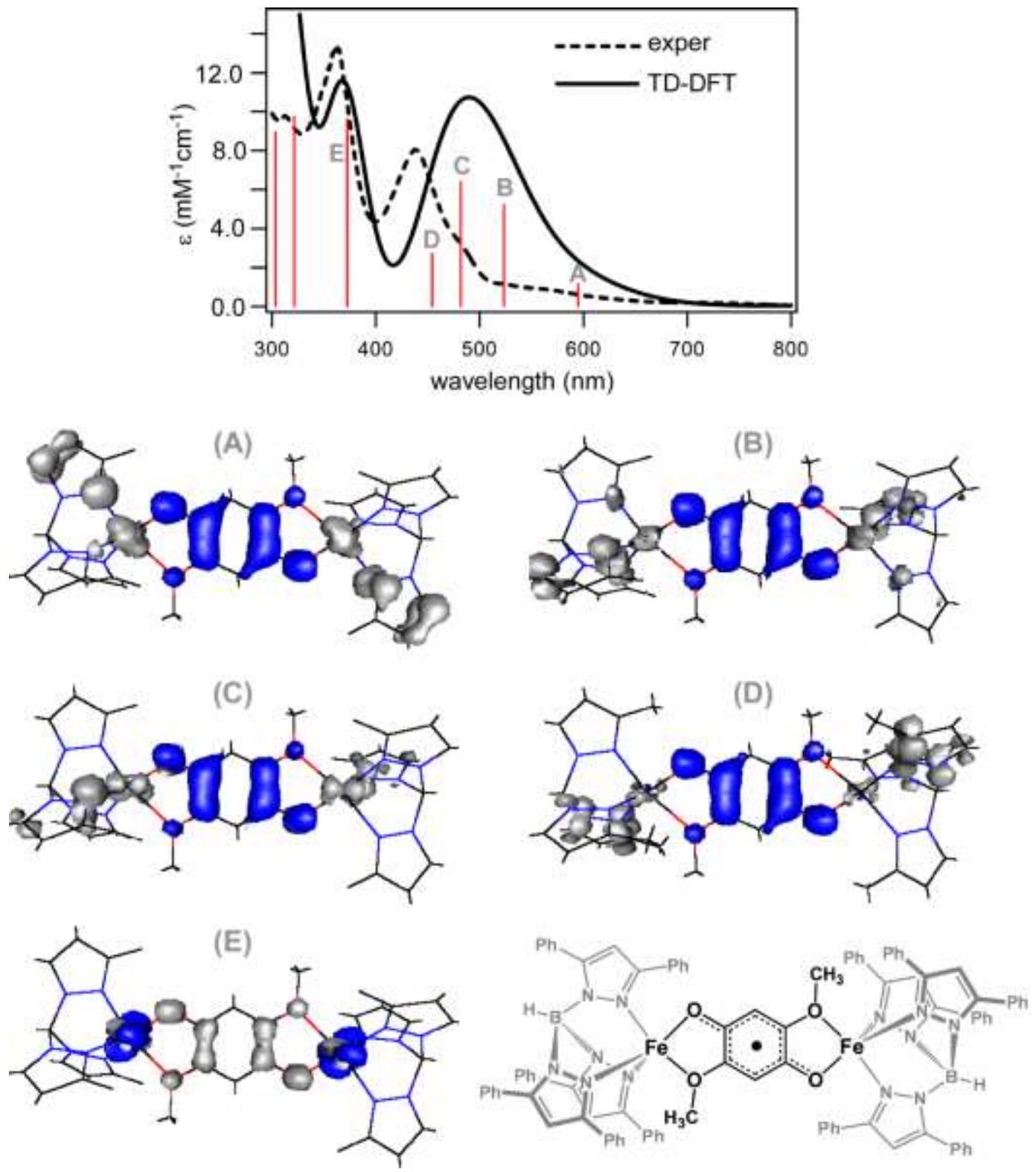

Figure S5. Top: Experimental (dashed) and TD-DFT computed (solid line) absorption spectra for [2] $\mathrm{PF}_{6}$. Red sticks represent the energies and intensities of prominent transitions in the TD-DFT spectrum. Bottom: Electron density difference maps (EDDMs) for the computed transitions labeled in the upper spectrum. Blue and grey regions indicate gain and loss of electron density, respectively.

Chemical Communications, Vol. 49, No. 58 (July 2013): pg. 6531-6533. DOI. This article is @ Royal Society of Chemistry and permission has been granted for this version to appear in e-Publications@Marquette. Royal Society of Chemistry does not grant permission for this article to be further copied/distributed or hosted elsewhere without the express permission from Royal Society of Chemistry. 


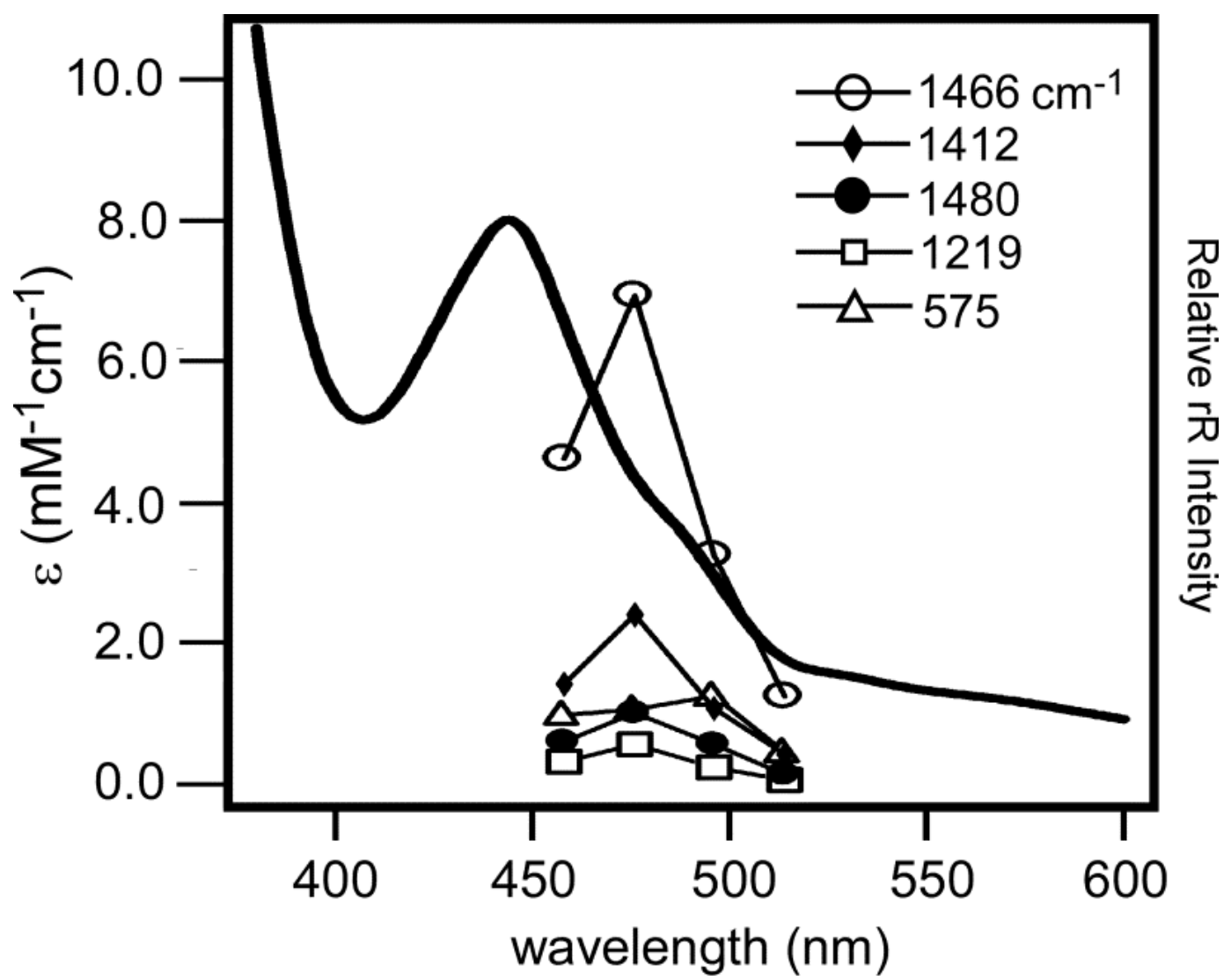

Figure S6. $r R$ excitation profiles of various modes of $[2] \mathrm{PF}_{6}$ measured with a frozen $\mathrm{CD}_{2} \mathrm{Cl}_{2}$ solution $([\mathrm{Fe}]=3.1 \mathrm{mM})$ at $77 \mathrm{~K}$. Profiles are superimposed on the room temperature absorption spectrum of [2] $\mathrm{PF}_{6}$ in $\mathrm{CH}_{2} \mathrm{Cl}_{2}$.

\section{References}

1. D. Hanss, M. E. Walther and O. S. Wenger, Chem. Commun., 2010, 46, 7034-7036.

2. N. Kitajima, K. Fujisawa, C. Fujimoto, Y. Morooka, S. Hashimoto, T. Kitagawa, K. Toriumi, K. Tatsumi and A. Nakamura, J. Am. Chem. Soc., 1992, 114, 1277-1291.

3. A. E. Baum, H. Park, D. N. Wang, S. V. Lindeman and A. T. Fiedler, Dalton Trans., 2012, 41, 12244-12253.

4. S. Stoll and A. Schweiger, Journal of Magnetic Resonance, 2006, 178, 4255.

5. G. M. Sheldrick, Acta Crystallogr. Sect. A, 2008, 64, 112-122.

6. O. V. Dolomanov, L. J. Bourhis, R. J. Gildea, J. A. K. Howard and H. Puschmann, J. Appl. Crystallogr., 2009, 42, 339-341.

7. F. Neese. 
NOT THE PUBLISHED VERSION; this is the author's final, peer-reviewed manuscript. The published version may be accessed by following the link in the citation at the bottom of the page.

8. (a) A. D. Becke, J. Chem. Phys., 1986, 84, 4524-4529; (b) J. P. Perdew, Physical Review B, 1986, 33, 8822-8824.

9. (a) A. D. Becke, J. Chem. Phys., 1993, 98, 5648-5652; (b) C. T. Lee, W. T. Yang and R. G. Parr, Physical Review B, 1988, 37, 785-789.

10. (a) A. Schafer, H. Horn and R. Ahlrichs, J. Chem. Phys., 1992, 97, 25712577; (b) A. Schafer, C. Huber and R. Ahlrichs, J. Chem. Phys., 1994, 100, 5829-5835.

11. (a) R. E. Stratmann, G. E. Scuseria and M. J. Frisch, J. Chem. Phys., 1998, 109, 8218-8224; (b) M. E. Casida, C. Jamorski, K. C. Casida and D. R. Salahub, J. Chem. Phys., 1998, 108, 4439-4449; (c) R. Bauernschmitt and R. Ahlrichs, Chem. Phys. Lett., 1996, 256, 454464.

12. (a) S. Hirata and M. Head-Gordon, Chem. Phys. Lett., 1999, 314, 291299; (b) S. Hirata and M. Head-Gordon, Chem. Phys. Lett., 1999, 302, 375-382.

13. L. Laaksonen, J. Mol. Graph., 1992, 10, 33-\&.

Chemical Communications, Vol. 49, No. 58 (July 2013): pg. 6531-6533. DOI. This article is @ Royal Society of Chemistry and permission has been granted for this version to appear in e-Publications@Marquette. Royal Society of Chemistry does not grant permission for this article to be further copied/distributed or hosted elsewhere without the express permission from Royal Society of Chemistry. 